\title{
Distribution of Pythium porphyrae, the Causal Agent of Red Rot Disease of Porphyrae spp., in the Ariake Sea, Japan
}

\author{
Y. Kawamura and K. Yokoo, Saga Prefectural Ariake Fisheries Research and Development Center, Saga 849-0313, \\ Japan; and M. Tojo and M. Hishiike, Graduate School of Agriculture and Biological Sciences, Osaka Prefecture \\ University, Sakai, Osaka 599-8531, Japan
}

\begin{abstract}
Kawamura, Y., Yokoo, K., Tojo, M., and Hishiike, M. 2005. Distribution of Pythium porphyrae, the causal agent of red rot disease of Porphyrae spp., in the Ariake Sea, Japan. Plant Dis. 89:1041-1047.

Distribution of Pythium porphyrae, the causal agent of red rot disease of Porphyra spp., in seafloor sediment was investigated in the Ariake Sea, Japan. A total of 170 samples of each $200 \mathrm{ml}$ of sediment was collected from the seafloor at a total of 13 sites across the sea from 1998 to 2002. Each sample was filtered through two layers of nylon mesh with pore sizes of 100 and 15 $\mu \mathrm{m}$. The residue on $15 \mu \mathrm{m}$ mesh was assayed by a soil plating technique using a semiselective medium for $P$. porphyrae and by polymerase chain reaction (PCR) using species-specific primers. $P$. porphyrae were detected in 6 out of 13 sites and 2 out of 10 sites surveyed by soil plating and PCR, respectively. The representative isolate of $P$. porphyrae from the sediment was identical to the Porphyra thallus isolate from the same sea based on pathogenicity to the thallus, morphology, and rDNA internal transcribed spacer sequences. Recovery of $P$. porphyrae propagules in the sediment was up to $60 \mathrm{CFU}$ per $100 \mathrm{ml}$ of the fresh sample and was consistently higher in May than in the other months. The results suggest that $P$. porphyrae is distributed in the seafloor sediment in a wide area of the Ariake Sea.
\end{abstract}

Additional keyword: nori

Porphyra spp., nori in Japanese, are marine red algae cultivated as a commercially important edible seaweed. The Ariake Sea is the main production area in Japan. Red rot disease is the most common and serious problem of Porphyra spp. The disease occurs throughout the farming period from October to March, and yield reduction is estimated to reach $20 \%$ in the Ariake Sea (Y. Kawamura, unpublished). Red rot disease was first reported by Arasaki (3), and the causal agent was named Pythium porphyrae by Takahashi et al. (23). The pathogen severely infects nori thalli and causes death of the host within a few days $(8,9)$. The pathogen spreads by means of zoospores, which are released into seawater $(4,24)$. Epidemics after the release of $P$. porphyrae zoospores in the sea have been well investigated $(2-6,9,24)$.

However, information on primary sources of the inocula initiating epidemics of the disease in nature has been limited.

Corresponding author: M. Tojo

E-mail: tojo@plant.osakafu-u.ac.jp

Current address of M. Hishiike: Research Laboratory, Riken Green, Iwata, Shizuoka 437-1218, Japan.

Accepted for publication 17 May 2005.

DOI: 10.1094/PD-89-1041

(C) 2005 The American Phytopathological Society
Several studies have been done on the behavior of $P$. porphyrae when the host plant is absent. For example, $P$. porphyrae oospores are produced in nori thalli throughout the farming period (3-6) and remain in seawater after it decays (5). Zoospores of $P$. porphyrae derived from oversummering oospores caused red rot disease on healthy thalli under laboratory conditions $(5,7)$. Oospores of $P$. porphyrae were viable for at least 2 months in sterile seawater at room temperature of 14 to $29^{\circ} \mathrm{C}$ (29). Based on these previous studies, the pathogen may oversummer primarily as oospores in the thallus tissues and continue to survive in seafloor sediments after decay of the thallus. The potential of seafloor sediments for carryover of $P$. porphyrae inoculum to the next farming period has been suggested (7). However, survival of the pathogen in the seafloor sediments in natural environments has not been elucidated.

Pythium marinum Sparrow is a causal agent of a rot disease on Porphyra spp. on the Pacific and Atlantic coasts of North America (12-15) and is considered to be a synonym of $P$. porphyrae $(8,18,21)$. There have also been no studies conducted on survival of $P$. marinum in seafloor sediment in natural environmental conditions.

$P$. porphyrae can be detected from artificially infested sterile sediment by a soil plating technique using a semiselective medium and by nested polymerase chain reaction (PCR) using primer sets to amplify $P$. porphyrae genomic DNA (28). The pathogen has been detected from seawater by direct PCR using a specific primer to amplify internal transcribed spacer (ITS) regions of rDNA $(18,19)$. Since the density of $P$. porphyrae propagules is very low in the seafloor sediments in naturally infested areas, its detection has been unsuccessful by direct assays using these techniques (K. Yokoo, unpublished). Extraction of oospores from soil by filtering has been used to quantitatively assay Peronospora viciae (25). The filtering assay prior to performing soil plating and PCR techniques are considered to be effective to detect $P$. porphyrae from seafloor sediment.

The objectives of this study were to clarify the distribution and frequency of $P$. porphyrae propagules in the seafloor sediment of the Ariake Sea between farming seasons. The importance of the propagules in the seafloor sediment as a source of primary infection for this disease was also investigated.

\section{MATERIALS AND METHODS}

Sampling of seafloor sediment. Samples of seafloor sediment were collected from a total of 13 sites (Fig. 1) across the northern part of the Ariake Sea $\left(33^{\circ} 02^{\prime} \mathrm{N}\right.$, $130^{\circ} 12^{\prime} \mathrm{E}$ ) from May 1998 to October 2002. The sampling sites had a water depth of 5 to $20 \mathrm{~m}$ at high tide and 0 to $15 \mathrm{~m}$ at low tide. Two 500-ml cores of seafloor surface sediments were collected from each site using an Ekman dredge (Rigosha, Tokyo, Japan). A 200-ml sediment sample was collected from the 5-mm surface layer of each core. The sediment consisted of fine-particle silt and did not contain debris of nori thalli. The average particle size, chemical oxygen demand, and $\mathrm{H}_{2} \mathrm{~S}$ concentration of the samples from site 4 (Fig. 1) were $6.5 \mu \mathrm{m}, 16.6$ to $21.4 \mathrm{mg} / \mathrm{g}$, and 0.5 to $0.7 \mathrm{mg} / \mathrm{g}$, respectively. Surface temperature of the seafloor was measured once at the time of sampling by a thermometer at site 4 (Fig. 1). The samples were kept cool in an ice chest during transport to the laboratory. Samples were subjected to filtering the same day.

Filtering of seafloor sediment. The 200-ml sediment sample was added to 1 liter of sterile seawater and thoroughly mixed using a stirring bar. The suspension was poured into a bag made of a $15-\mu \mathrm{m}$ nylon mesh (NBC, Tokyo, Japan) and gen- 
tly shaken in 2 liters of sterile seawater. Subsequently, the suspension was filtered through a $100-\mu \mathrm{m}$ and a $15-\mu \mathrm{m}$ nylon mesh. The residue on the $15-\mu \mathrm{m}$ nylon mesh was washed with $100 \mathrm{ml}$ of sterile seawater and suspended in $50 \mathrm{ml}$ of sterile seawater in a tube.

Isolation of $P$. porphyrae by soil plating technique. The residue samples collected were used for the quantitative isolation of $P$. porphyrae by the soil plating technique using a semiselective medium. Fifty milliliters of filtered suspension was centrifuged at $200 \times g$ for $1 \mathrm{~min}$. The supernatant and top 2-mm layer of the precipitate were poured into a tube and incubated for $12 \mathrm{~h}$ at $15^{\circ} \mathrm{C}$. The newly obtained supernatant was removed, and the precipitate was suspended in $10 \mathrm{ml}$ of sterile seawater. While gently agitating the test tube to suspend the precipitate, $1 \mathrm{ml}$ of the suspension was transferred onto five petri dishes containing a medium semiselective for $P$. porphyrae (extract from $20 \mathrm{~g}$ of frozen corn kernels, $15 \mathrm{~g}$ of agar [Wako, Osaka, Japan], $100 \mathrm{mg}$ of vancomycin hydrochloride [Wako], $100 \mathrm{mg}$ of Penicillin $\mathrm{G}$ potassium [Wako], $100 \mathrm{mg}$ of Ampicillin anhydrous [Sigma, St. Louis, MO, USA], and 1,000 $\mathrm{ml}$ of seawater with salinity of $2.0 \%, \mathrm{pH} 7.5$ ). The suspension was spread on each plate with a sterile glass rod and incubated in the dark at $18^{\circ} \mathrm{C}$. Isolation dishes were examined

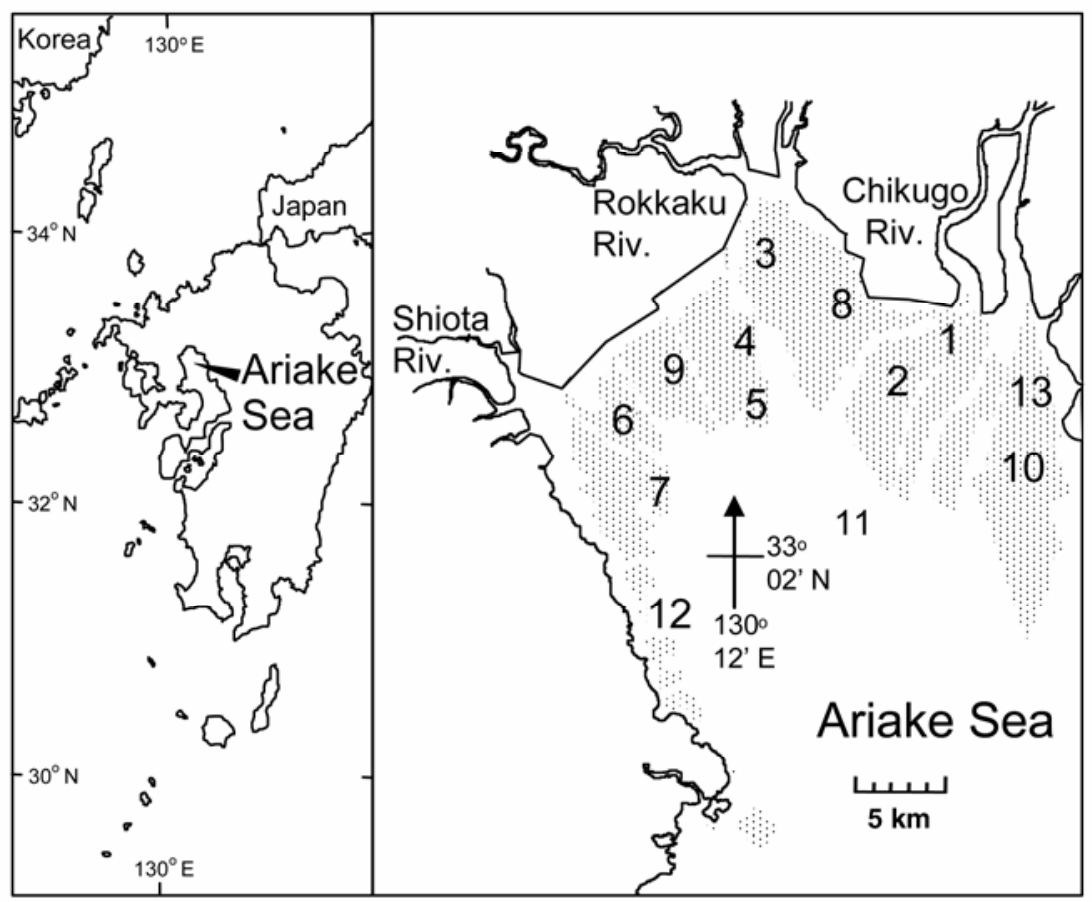

Fig. 1. Sampling sites of seafloor sediment, the cultivation area of Porphyra spp. (shaded areas), and major river mouths in the Ariake Sea, Japan.

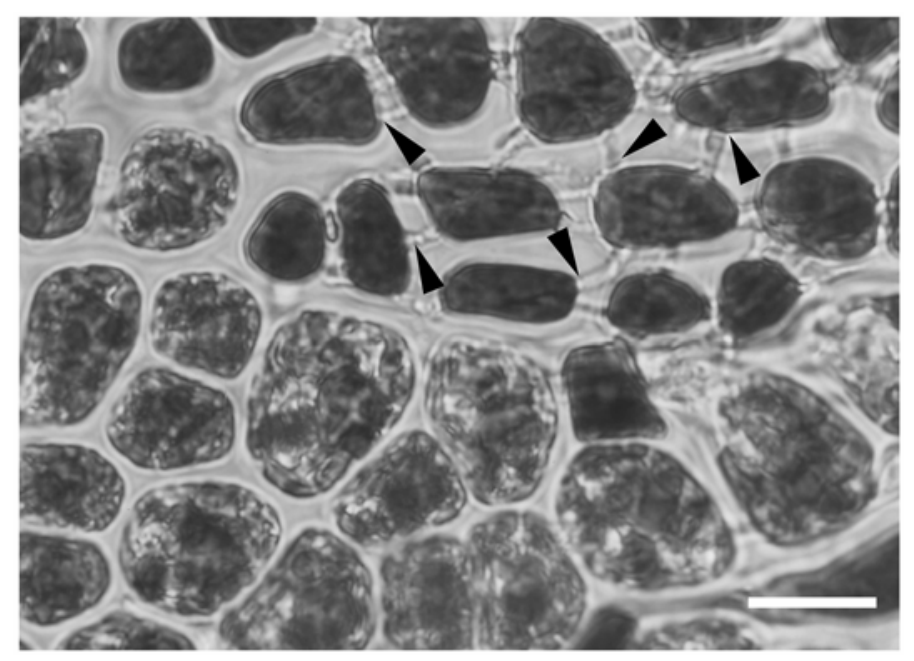

Fig. 2. Inter- and intracellular growth of hyphae of Pythium porphyrae in cells of the thallus of Porphyra yezoensis. Infected cells (upper) were killed and discolored. Arrowheads indicate catenulation of the hyphae into the cells. Bar represents $20 \mu \mathrm{m}$. daily for colony growth, and the number of fungal colonies was noted over a period of at least 14 days. All fungal colonies developed were rinsed with $50 \mathrm{ml}$ of sterile seawater and transferred to seawater corn extract agar (SCMA, extract from $20 \mathrm{~g}$ of frozen corn kernels, $15 \mathrm{~g}$ of agar [Wako], and $1,000 \mathrm{ml}$ of half-strength of seawater with salinity of $1.5 \%, \mathrm{pH} 7.5$ ). Single hyphal tips from the cultures were stored in petri dishes containing $15 \mathrm{ml}$ of SCMA at 18 to $20^{\circ} \mathrm{C}$ until use.

Pathogenicity test. Fungal isolates causing red rot disease on nori thalli were chosen from all isolates by pathogenicity test as follows. Hyphal tips of all fungal colonies were inoculated to healthy thalli of nori (Porphyra yezoensis Ueda) in 200 $\mathrm{ml}$ of sterile seawater (2\% salinity, $\mathrm{pH} 7.5$ ) in a $200-\mathrm{ml}$ flask. The flask was aerated with filtered sterile air $\left(300 \mathrm{ml} \mathrm{min}^{-1}\right)$ by an air pump and placed in a growth chamber at $18 \pm 1{ }^{\circ} \mathrm{C}$ with continuous light (46 to $65 \mu \mathrm{mol} \cdot \mathrm{m}^{-2} \cdot \mathrm{s}^{-1}$ measured at the bottom level of the flasks) for 5 to 7 days. Thalli exhibiting red rot disease symptoms were examined with a compound microscope to confirm infection of host cells (Fig. 2). Infected thalli were rinsed with $50 \mathrm{ml}$ of sterile seawater and transferred to SCMA and incubated in the dark at $18^{\circ} \mathrm{C}$. Hyphal tips growing on the medium were transferred to SCMA plates and maintained at $18^{\circ} \mathrm{C}$ until use. Healthy nori thalli inoculated with the isolate S44 of $P$. porphyrae from nori thallus in the Ariake Sea were used for comparison. $P$. porphyrae isolate S44 was deposited in the National Institute of Technology and Evaluation Biological Resource Center, Japan (NBRC), and the Ministry of Agriculture, Forestry and Fisheries of Japan (MAFF), under accession nos. NBRC100633 and MAFF239483, respectively.

Morphological examination. Isolates that were pathogenic in the preliminary experiments were inoculated onto SCMA plates and incubated for 7 to 30 days at $22^{\circ} \mathrm{C}$. Mycelia developed on the medium were placed into 90-mm-diameter petri dishes containing $10 \mathrm{ml}$ of sterile seawater mixture (SSW) containing seawater: deionized water:pond water (1:1:2) and incubated at $22^{\circ} \mathrm{C}$ for 2 days according to Takahashi et al. (23). They were also grown by the grass blade culture method (16) modified as follows. SSW was used instead of distilled water. Fresh bentgrass blades were cut to approximately $3 \mathrm{~mm}$ long, added to a beaker containing SSW, covered by aluminum foil, and autoclaved. Isolates were inoculated on the leaf blades in petri dishes and incubated at $22^{\circ} \mathrm{C}$ for 2 days. Approximately $20 \mathrm{ml}$ of SSW was added to the infected leaf blades in the plate and incubated further at 18 to $22^{\circ} \mathrm{C}$ for 1 to 7 days. Morphological characteristics examined were: dimensions of hyphae, oogonia, oospores, hyphal swellings, oospore wall thickness, vesicles and encysted 
zoospores, the percentages of intercalary oogonia, diclinous antheridia and intercalary hyphal swellings, the number of antheridia per oogonium, number of zoospores per vesicle, and sporangial shape. Morphological identification was based on the keys of van der Plaats-Niterink (26) and description of Takahashi et al. (23). To select a representative isolate for morphological description, we examined at least five of each of the organs listed above by a compound microscopy on 133 isolates of $P$. porphyrae from seafloor sediment. Then, 30 of each of the organs were examined for isolate G1. Isolate G1 was deposited in NBRC and MAFF under accession nos. NBRC100634 and MAFF239484, respectively. The isolate S44 of $P$. porphyrae from nori thallus described earlier was used for morphological comparisons.

Molecular identification. $P$. porphyrae isolate $\mathrm{G} 1$ from seafloor sediment and the isolate S44 from nori thallus were used. DNA was extracted according to the method of Martin and Kistler (17) with a slight modification. Seed cultures were grown on SCMA plates for 10 days at $18^{\circ} \mathrm{C}$. A weft of mycelium was then scraped from slants and inoculated into seawater corn meal liquid ( $20 \mathrm{~g}$ of frozen corn kernels, $1,000 \mathrm{ml}$ of half-strength seawater with salinity of $1.5 \%, \mathrm{pH} 7.5$ ) in 90-mm-diameter petri dishes. After 7 days of incubation at $22^{\circ} \mathrm{C}$, hyphal mats were harvested from plates and rinsed several times in deionized water. Excess water was removed from mycelia by pressing with a paper towel. A 1- to 2-g portion of mycelial mat was placed in a prechilled mortar, frozen with liquid nitrogen, and ground into a fine powder. Mycelial powder was suspended in $15 \mathrm{ml}$ of extraction buffer (17) in a polypropylene centrifuge tube and incubated at $65^{\circ} \mathrm{C}$ for $10 \mathrm{~min}$, and 7.5 $\mathrm{ml}$ of $5 \mathrm{M}$ potassium acetate was added per $15 \mathrm{ml}$ of extraction buffer. The solution was incubated for $20 \mathrm{~min}$ in an ice bath and centrifuged at $3,000 \times g$ for $20 \mathrm{~min}$ at $4^{\circ} \mathrm{C}$. The supernatant was poured through a nylon mesh (161- $\mu$ m opening, NBC) into a fresh tube containing $15 \mathrm{ml}$ of isopropanol. DNA was precipitated by overnight incubation at $-20^{\circ} \mathrm{C}$ and pelleted by centrifugation at $3,000 \times g$ for $30 \mathrm{~min}$ at $4^{\circ} \mathrm{C}$. Pellets were resuspended in $2 \mathrm{ml}$ of buffer containing $20 \mathrm{mM}$ Tris- $\mathrm{HCl}$ and $10 \mathrm{mM}$ EDTA ( $\mathrm{pH} 8.0)$, then treated with proteinase K $(200 \mu \mathrm{g} / \mathrm{ml}$, Sigma) and RNase (100 $\mu \mathrm{g} / \mathrm{ml}$, Sigma) for $60 \mathrm{~min}$ each. The suspension was treated once with phenol:chloroform:isoamyl alcohol $(25: 24: 1)$ and twice with chloroform:isoamyl alcohol (24:1). DNA was precipitated by adding $0.7 \mathrm{vol}$ of isopropanol, incubating at $-20^{\circ} \mathrm{C}$ for at least $1 \mathrm{~h}$, and centrifuging at 18,000 $\times g$ for $15 \mathrm{~min}$. DNA pellets were washed with $70 \%$ cold ethanol, dried in vacuo, and dissolved in $100 \mu \mathrm{l}$ of TE buffer $(10 \mathrm{mM}$ Tris-HCl, pH 8.0, 1 mM EDTA).
The ITS regions containing ITS1 and ITS2 and intervening 5.8S rDNA were amplified by using a Perkin Elmer 9700 thermocycler (Perkin Elmer, Foster, CA, USA). The primers ITS5 and ITS4 (27) were used. The amplification program consisted of pre-denaturation at $95^{\circ} \mathrm{C}$ for 5 min, 35 amplification cycles at $95^{\circ} \mathrm{C}$ for 30 $\mathrm{s}, 55^{\circ} \mathrm{C}$ for $30 \mathrm{~s}$, and $72^{\circ} \mathrm{C}$ for $1 \mathrm{~min}$, and final incubation at $72^{\circ} \mathrm{C}$ for $7 \mathrm{~min}$ to complete the last extension. The final products were purified using QIAquick PCR Purification Kit (Qiagen, Valencia, CA, USA) according to the manufacturer's instructions. The dye terminator cycle sequence reaction was performed in GeneAmp PCR systems 2700 (Applied Biosystems, Foster City, CA, USA) with BigDye Terminator Sequencing Kits Version 1.1 (Applied Biosystems) according to the manufacturer's recommendations, followed by electrophoresis and analysis using an automated DNA sequencer (ABI PRIZM 3100; Applied Biosystems). The ITS regions were sequenced in both directions using primers ITS1, ITS2, ITS3, and ITS4 (27). Sequence data were analyzed with GENETYX version 6 (GENETYX, Tokyo, Japan) and deposited in the DNA Data Bank of Japan (DDBJ) database under accession no. AB185111. Similarity searches were performed using the BLAST program (1).

Detection of $P$. porphyrae by PCR. A 50-ml suspension of the filtered sample was amended with $500 \mathrm{mg}$ of polyvinylpolypyrrolidone (Sigma) and centrifuged at $200 \times g$ for $1 \mathrm{~min}$. The supernatant $(45$ $\mathrm{ml}$ ) was poured into a tube and centrifuged at $15,000 \times g$ for $10 \mathrm{~min}$. The supernatant was removed, and the precipitate was suspended in $15 \mathrm{ml}$ of extraction buffer (17) in a polypropylene centrifuge tube. Further steps for the DNA extraction were the same as described above.

Table 1. Morphology and dimension of organs of Pythium porphyrae from seafloor sediment of the Ariake Sea and reference data of the species

\begin{tabular}{|c|c|c|c|c|}
\hline & $\begin{array}{c}\text { Isolate G1 } \\
\text { from seafloor } \\
\text { sediment }\end{array}$ & $\begin{array}{c}\text { Isolate } S 44 \\
\text { from nori } \\
\text { thallus }\end{array}$ & $\begin{array}{l}\text { Park et al. } \\
\quad(20)\end{array}$ & $\begin{array}{l}\text { Takahashi } \\
\text { et al. (23) }\end{array}$ \\
\hline Width of hyphae $(\mu \mathrm{m})$ & $<4.7$ & $<4.7$ & $<5.4$ & $<4.5$ \\
\hline Oogonium diameter $(\mu \mathrm{m})$ & $16.0-23.0$ & $16.1-23.0$ & $16.2-29.7$ & $14.5-19.5$ \\
\hline $\begin{array}{l}\text { Ratio of intercalary } \\
\text { oogonium }(\%)\end{array}$ & 13.3 & 23.3 & $\begin{array}{l}\text { Intercalary } \\
\text { or terminal }\end{array}$ & $\begin{array}{l}\text { Intercalary } \\
\text { rarely terminal }\end{array}$ \\
\hline Oospore diameter $(\mu \mathrm{m})$ & $14.0-21.3$ & $14.0-21.5$ & $17.2-24.6$ & $13.2-17.5$ \\
\hline Oospore wall thickness $(\mu \mathrm{m})$ & $0.8-1.8$ & $1.0-2.0$ & $1.1-2.4$ & Thick-walled \\
\hline $\begin{array}{l}\text { Number of antheridia } \\
\text { per oogonium }\end{array}$ & 1-2 & 1-3 & $2-4$ & $1-4$ \\
\hline $\begin{array}{l}\text { Ratio of diclinous } \\
\text { antheridium }(\%)\end{array}$ & 92.5 & 95.5 & $\begin{array}{l}\text { Diclinous or } \\
\text { monoclinous }\end{array}$ & Diclinous \\
\hline $\begin{array}{l}\text { Diameter of globose hyphal } \\
\text { swellings }(\mu \mathrm{m})\end{array}$ & $16.0-27.5$ & $12.8-24.2$ & $13.0-31.2$ & Not described \\
\hline $\begin{array}{l}\text { Ratio of intercalary hyphal } \\
\text { swellings (\%) }\end{array}$ & 20.0 & 46.7 & $\begin{array}{l}\text { Terminal or } \\
\text { intercalary }\end{array}$ & $\begin{array}{l}\text { Terminal or } \\
\text { intercalary }\end{array}$ \\
\hline Sporangia & Filamentous & Filamentous & Filamentous & Filamentous \\
\hline Vesicle diameter $(\mu \mathrm{m})$ & 22.1-39.5 & $22.1-34.8$ & $16.2-42.2$ & Not described \\
\hline $\begin{array}{l}\text { Number of zoospores } \\
\text { per vesicle }\end{array}$ & $3-53$ & $14-30$ & 9-39 & 6-17 \\
\hline $\begin{array}{l}\text { Diameter of encysted } \\
\text { zoospore }(\mu \mathrm{m})(\text { mean } \pm S E)\end{array}$ & $9.3 \pm 0.4$ & $8.8 \pm 0.3$ & $7.7 \pm 0.5$ & Not described \\
\hline
\end{tabular}

During February to October 2000, amplification was done by nested PCR as described previously (28) with slight modifications. In the first round of the nested PCR, primer OPB-07 (5'GGTGACGCAG-3', Operon Technologies, Alameda, CA, USA) was used. Each 25- $\mu \mathrm{l}$ reaction mixture contained $2 \mu \mathrm{l}$ of DNA extract from seafloor sediment as a template and $0.04 \mu \mathrm{M}$ primer OPB-07, 0.2 mM dNTPs (Takara Bio, Ohtsu, Japan), 1× PCR buffer (Takara Bio), and $0.1 \mu \mathrm{l}$ of Taq DNA polymerase (Takara Bio). Sterile water was used as a negative control. Purified DNA (100 ng) from $P$. porphyrae isolate G1 was used as a positive control The mixtures were incubated at $94^{\circ} \mathrm{C}$ for 3 min followed by 40 amplification cycles each consisting of $94^{\circ} \mathrm{C}$ for $1 \mathrm{~min}, 35^{\circ} \mathrm{C}$ for $1 \mathrm{~min}$, and $72^{\circ} \mathrm{C}$ for $2 \mathrm{~min}$. The second round of the nested PCR was performed with $1 \mu \mathrm{l}$ of the first PCR product as a template, under the same PCR conditions as described previously, except that $0.04 \mu \mathrm{M}$ each of primer, API (5'TACAAGTCCTGGCCCCTCTCGTGT-3') and APII (5'-GAATGCGAGTGGCTCGACGCGTCT-3'), were used instead of the primer OPB-07. These primers were designed to amplify the specific 373-bp DNA fragment amplified by the first round of PCR (28). PCR reaction products $(3.4 \mu \mathrm{l})$ were electrophoresed with $0.6 \mu \mathrm{l}$ of loading buffer on a $1 \%$ agarose gel, stained with ethidium bromide, and visualized under UV irradiation.

Between May 2001 and October 2002, DNA amplification was done by direct PCR using a species-specific primer to amplify ITS regions containing ITS1 and ITS2 and the intervening 5.8S rDNA of $P$. porphyrae (18). PCR was performed with $2 \mu \mathrm{l}$ of the DNA extracts from seafloor sediments as a template, and PCR conditions were the same as for the nested PCR. 


\section{RESULTS}

Isolation, pathogenicity determination, and identification. By the soil plating technique, a total of 467 fungal isolates were obtained from the seafloor sediment at 13 sites in the northern part of the Ariake Sea from May 1998 to October 2002. Among these isolates, 133 isolates inoculated caused red rot disease symptoms on healthy thalli of nori within 7 days after inoculation (Fig. 2). The other 334 fungal isolates were not pathogenic on the plant. They were morphologically characterized as unknown Pythium and Deuteromycetes (data not shown).

All pathogenic isolates were morphologically similar to each other. Morphological features of a representative isolate G1 from the seafloor sediment were identical to those of isolate $\mathrm{S} 44$ from nori thallus in the Ariake Sea (Table 1). The morphology of isolate G1 was comparable to the descriptions of Takahashi et al. (23) and Park et al. (20) (Table 1). Typical morphological features of isolate G1 were illustrated in Figure 3. Cardinal temperatures of isolate G1 on SCMA ranged from 1 to $28^{\circ} \mathrm{C}$, with an optimum temperature at $25^{\circ} \mathrm{C}$. Daily growth rate at $25^{\circ} \mathrm{C}$ was 4.0 $\mathrm{mm}$.

The sequences of the ITS1 and ITS2 and 5.8S rDNA regions of $P$. porphyrae isolate $\mathrm{G} 1$ from seafloor sediment were identical to those of isolate S44 from nori thallus and published data on this species (18). Full length of the sequences was $784 \mathrm{bp}$. The location of ITS1 was from nucleotide 1 to 174 ; the 5.8S rRNA gene from nucleotide 175 to 332 ; and ITS2 from nucleotide 333 to 784 . The nucleotide sequence data are available in the DDBJ/EMBL/GenBank databases under accession no. AB185111. Based on these results, isolate G1 was identified as Pythium porphyrae Takahashi \& Sasaki, and it was concluded that all pathogenic seafloor isolates belonged to the same species.

Distribution and frequency. A total of 133 isolates of $P$. porphyrae were recovered from seafloor sediment at sites $3,4,5$,
8,10 , and 12 by the soil plating technique from May 1998 to October 2002 (Fig. 1, Table 2). Density of $P$. porphyrae propagules was 0 to $60.0 \mathrm{CFU}$ per $100 \mathrm{~g}$ of fresh sediment. During the off-season of farming from May to October, density fluctuated seasonally and was consistently high in May.

$P$. porphyrae was detected from the seafloor sediment in May and August 2000 from site 4 by nested PCR using the $P$. porphyrae-specific primers of Yokoo et al. (28) (Fig. 4, Table 3), and in May 2002 from sites 4 and 10 by direct PCR using the primer of Park et al. (18) (Fig. 5, Table 4).

\section{DISCUSSION}

It has been proposed that $P$. porphyrae survives during the off-season of the farming period in the seafloor $(4,5,7,28,29)$, but there was no evidence indicating its presence in the natural environmental conditions. We elucidated, for the first time, the survival of $P$. porphyrae in seafloor sedi-

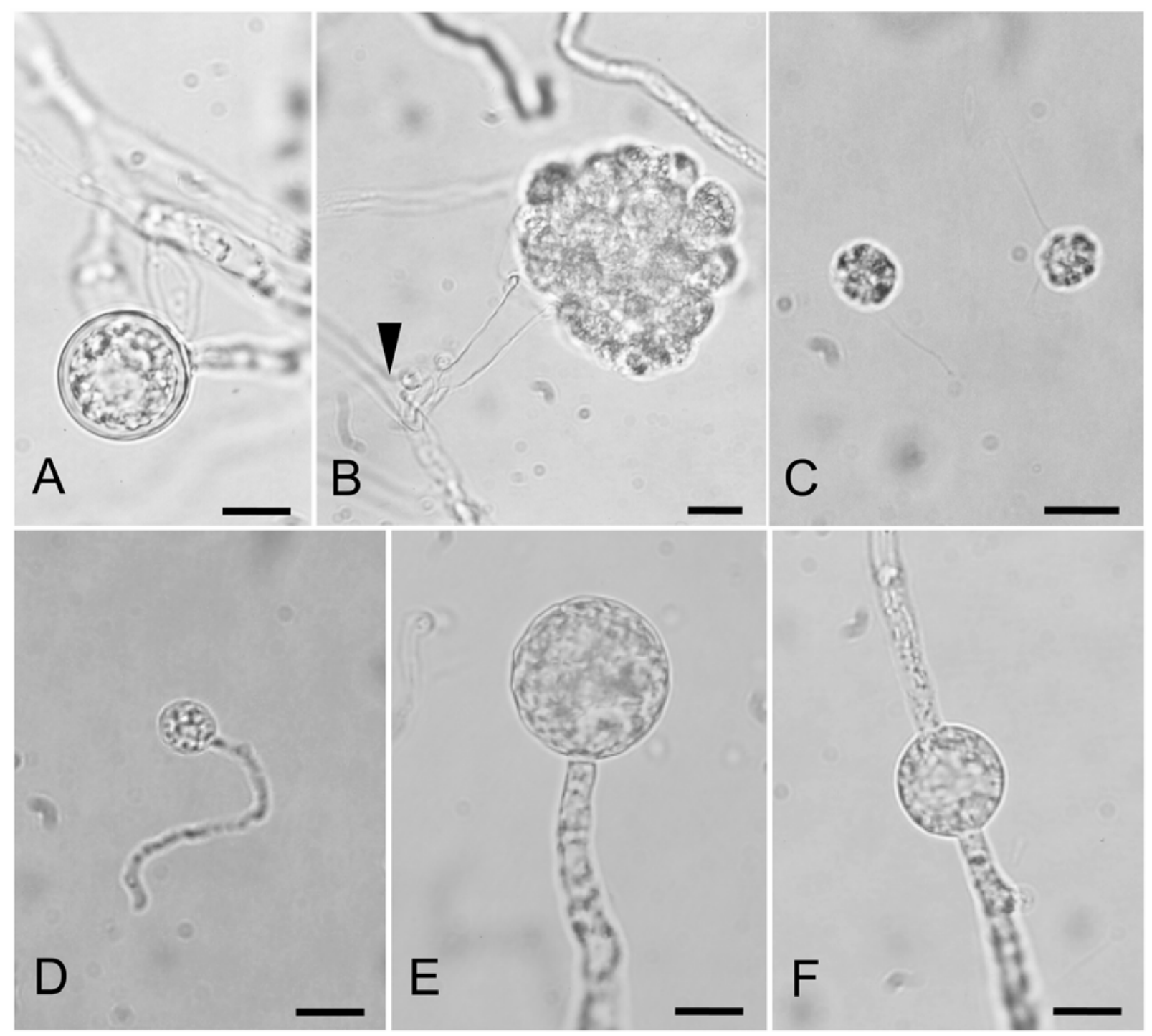

Fig. 3. Morphology of Pythium porphyrae detected in seafloor sediment of the Ariake Sea. Bars represent $10 \mu \mathrm{m}$. A, Plerotic oospore and two antheridia. B, Vesicle and filamentous sporangium (arrowhead). C, Zoospores with two flagella. D, Germination of a zoospore. E, A terminal globose hyphal swelling. F, An intercalary globose hyphal swelling. 
ment during the off-season of the farming period from May to October. Results from the soil plating and PCR detection techniques indicate that $P$ porphyrae propagules exist in the seafloor sediment across the northern part of the Ariake Sea. $P$. porphyrae isolates from the sediment were pathogenic on nori in the artificial inoculation tests. These results suggest that $P$. porphyrae propagules exist in seafloor sediment in the Ariake Sea with the potential to serve as a primary inoculum source.

Density of $P$. porphyrae propagules fluctuated seasonally and was higher in May than in other months surveyed. Recovery of $P$. porphyrae propagules was low and inconsistent from June to October. This fluctuation may imply that the $P$. porphyrae populations in the seafloor sediment are influenced by farming practices. In the Ariake Sea, nori is cultured from October to March. The red rot disease on nori occurs through the farming period and is usually relatively severe during warm seasons. On the basis of our sea farm observations, diseased thalli are readily removed from cultivation nets by waves of seawater. They subsequently float, sink, and decompose. The growers tend to leave infected nori in the water at the end of the farming season in March because they are valueless. The frequent recovery of $P$. porphyrae in May corresponded with increasing amounts of nori thallus debris in the water. The present results combined with sea farm observations indicate that $P$. porphyrae in the seafloor sediment originates from infected debris of thalli accumulating at the end of the farming season. Based on our counts of very low inoculum densities during the warm period from May to October, fungal propagules likely are dormant during this period, and only a few are active in the seafloor environments. This result agrees with previous reports showing that $P$. porphyrae oospores remain dormant after the decay of the thallus $(7,10)$.

Since the density of $P$. porphyrae propagules was very low in naturally infested seafloor sediment, we failed to isolate the pathogen from the sediment by direct placement of sediment on the semiselective medium in our preliminary survey (Y. Kawamura, K. Yokoo, and M. Tojo, unpublished). The combination of filtering and soil plating or PCR successfully detected $P$. porphyrae. Extraction of oospores from soil by filtering has been used in a quantitative assay of Peronospora viciae (25). The procedure was based on the physical separation of the fraction containing fungal inoculum from soil particles of different sizes. Oospores and hyphal swellings of $P$. porphyrae had a diameter of 14.0 to $27.5 \mu \mathrm{m}$ (Table 1), whereas seafloor sediment in the Ariake Sea consists of fine silt and is normally up to $10 \mu \mathrm{m}$ in diameter. Therefore, the propagules can be concentrated by filtering with 100 and 15 $\mu \mathrm{m}$ mesh. The present study demonstrated that the filtering method is effective to collect $P$. porphyrae propagules from the seafloor sediment in the Ariake Sea.

In the Ariake Sea, red rot disease usually starts from sites near the river mouths that form infection centers. These sites are considered to be most important, supplying primary inoculum. In our results, however,

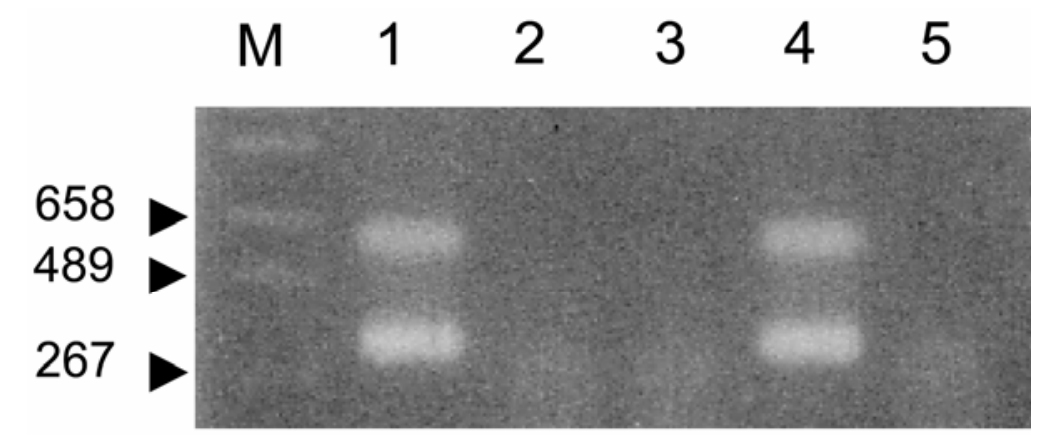

Fig. 4. Agarose gel electrophoresis of nested polymerase chain reaction (PCR) products amplified from DNA extracts from seafloor sediment of the Ariake Sea according to the procedure of Yokoo et al. (28). Lane M: pHY Marker (Takara Bio). Lanes 1, 2, and 3: Seafloor sediment samples from sites 4, 6, and 10 on 22 August 2000. Lane 4: Positive control (purified genomic DNA of Pythium porphyrae isolate G1). Lane 5: Negative control (autoclaved seafloor sediment).

Table 2. Populations of Pythium porphyrae in seafloor sediment of the Ariake Sea estimated by soil plating technique

\begin{tabular}{|c|c|c|c|c|c|c|c|c|c|c|c|c|c|c|}
\hline \multirow{2}{*}{$\begin{array}{l}\text { Sampling } \\
\text { date }\end{array}$} & \multirow{2}{*}{$\begin{array}{c}\text { Temp. at } \\
\text { seafloor } \\
\text { surface }\left({ }^{\circ} \mathbf{C}\right)^{\mathrm{a}}\end{array}$} & \multicolumn{13}{|c|}{ P. porphyrae population (CFU per $100 \mathrm{~g}$ of fresh soil) ${ }^{\mathrm{b}}$} \\
\hline & & $1^{c}$ & 2 & 3 & 4 & 5 & 6 & 7 & 8 & 9 & 10 & 11 & 12 & 13 \\
\hline \multicolumn{15}{|l|}{1998} \\
\hline 15 May & 19.0 & $\mathrm{nt}$ & $\mathrm{nt}$ & $\mathrm{nt}$ & 2.0 & $\mathrm{nt}$ & $\mathrm{nt}$ & $\mathrm{nt}$ & $\mathrm{nt}$ & $\mathrm{nt}$ & nt & $\mathrm{nt}$ & $\mathrm{nt}$ & $\mathrm{nt}$ \\
\hline 25 June & 22.6 & $\mathrm{nt}$ & nt & 1.0 & 1.0 & $\mathrm{nt}$ & nt & $\mathrm{nt}$ & $\mathrm{nt}$ & $\mathrm{nt}$ & $\mathrm{nt}$ & $\mathrm{nt}$ & $\mathrm{nt}$ & 0 \\
\hline 10 Aug & 29.4 & 0 & 0 & 0 & 0 & 0 & 0 & 0 & 0 & 0 & 0 & 0 & 1.0 & 0 \\
\hline $16 \mathrm{Sep}$ & 27.4 & $\mathrm{nt}$ & $\mathrm{nt}$ & 0 & 0 & $\mathrm{nt}$ & $\mathrm{nt}$ & $\mathrm{nt}$ & $\mathrm{nt}$ & $\mathrm{nt}$ & $\mathrm{nt}$ & $\mathrm{nt}$ & nt & $\mathrm{nt}$ \\
\hline \multicolumn{15}{|l|}{1999} \\
\hline 13 May & 19.8 & 0 & $\mathrm{nt}$ & 4.0 & 2.0 & 8.0 & 0 & $\mathrm{nt}$ & 8.0 & $\mathrm{nt}$ & 16.0 & 0 & 0 & 0 \\
\hline $25 \mathrm{Aug}$ & 26.9 & 0 & $\mathrm{nt}$ & 0 & 0 & 0 & 0 & $\mathrm{nt}$ & 0 & $\mathrm{nt}$ & 0 & 0 & 0 & 0 \\
\hline $20 \mathrm{Oct}$ & 15.8 & 0 & $\mathrm{nt}$ & 0 & 0 & 0 & 0 & nt & 0 & nt & 0.6 & 0 & 0 & 0 \\
\hline \multicolumn{15}{|l|}{2000} \\
\hline $22 \mathrm{Feb}$ & 8.0 & 0 & $\mathrm{nt}$ & 0 & 0 & 0 & 0 & $\mathrm{nt}$ & 0 & $\mathrm{nt}$ & 0 & 0 & 0 & 0 \\
\hline 11 May & 18.9 & nt & $\mathrm{nt}$ & nt & 1.0 & $\mathrm{nt}$ & $\mathrm{nt}$ & nt & $\mathrm{nt}$ & nt & 0 & nt & nt & $\mathrm{nt}$ \\
\hline 4 July & 24.6 & $\mathrm{nt}$ & $\mathrm{nt}$ & $\mathrm{nt}$ & 0 & $\mathrm{nt}$ & $\mathrm{nt}$ & $\mathrm{nt}$ & $\mathrm{nt}$ & $\mathrm{nt}$ & $\mathrm{nt}$ & $\mathrm{nt}$ & $\mathrm{nt}$ & $\mathrm{nt}$ \\
\hline 22 Aug & 27.3 & $\mathrm{nt}$ & $\mathrm{nt}$ & nt & 0 & $\mathrm{nt}$ & $\mathrm{nt}$ & $\mathrm{nt}$ & $\mathrm{nt}$ & $\mathrm{nt}$ & 0 & $\mathrm{nt}$ & nt & $\mathrm{nt}$ \\
\hline $26 \mathrm{Oct}$ & 17.1 & $\mathrm{nt}$ & $\mathrm{nt}$ & $\mathrm{nt}$ & 0 & $\mathrm{nt}$ & $\mathrm{nt}$ & $\mathrm{nt}$ & $\mathrm{nt}$ & $\mathrm{nt}$ & $\mathrm{nt}$ & $\mathrm{nt}$ & $\mathrm{nt}$ & $\mathrm{nt}$ \\
\hline \multicolumn{15}{|l|}{2001} \\
\hline 29 May & 22.0 & 0 & $\mathrm{nt}$ & 4.0 & 2.0 & 0 & 0 & 0 & 6.0 & 0 & 60.0 & $\mathrm{nt}$ & $\mathrm{nt}$ & $\mathrm{nt}$ \\
\hline 30 Aug & 27.1 & $\mathrm{nt}$ & $\mathrm{nt}$ & nt & 0 & $\mathrm{nt}$ & $\mathrm{nt}$ & $\mathrm{nt}$ & 0 & $\mathrm{nt}$ & 0 & $\mathrm{nt}$ & $\mathrm{nt}$ & $\mathrm{nt}$ \\
\hline $20 \mathrm{Nov}$ & 15.0 & $\mathrm{nt}$ & $\mathrm{nt}$ & nt & 0 & $\mathrm{nt}$ & $\mathrm{nt}$ & nt & 0 & nt & 0 & $\mathrm{nt}$ & nt & $\mathrm{nt}$ \\
\hline \multicolumn{15}{|l|}{2002} \\
\hline 10 May & 17.9 & $\mathrm{nt}$ & $\mathrm{nt}$ & $\mathrm{nt}$ & 4.0 & $\mathrm{nt}$ & $\mathrm{nt}$ & $\mathrm{nt}$ & $\mathrm{nt}$ & $\mathrm{nt}$ & 8.0 & $\mathrm{nt}$ & $\mathrm{nt}$ & $\mathrm{nt}$ \\
\hline $18 \mathrm{Sep}$ & 25.8 & $\mathrm{nt}$ & $\mathrm{nt}$ & nt & 0 & $\mathrm{nt}$ & $\mathrm{nt}$ & $\mathrm{nt}$ & $\mathrm{nt}$ & $\mathrm{nt}$ & 0 & $\mathrm{nt}$ & $\mathrm{nt}$ & $\mathrm{nt}$ \\
\hline 29 Oct & 15.0 & $\mathrm{nt}$ & $\mathrm{nt}$ & $\mathrm{nt}$ & 0.3 & $\mathrm{nt}$ & $\mathrm{nt}$ & $\mathrm{nt}$ & $\mathrm{nt}$ & $\mathrm{nt}$ & $\mathrm{nt}$ & $\mathrm{nt}$ & $\mathrm{nt}$ & $\mathrm{nt}$ \\
\hline
\end{tabular}

${ }^{a}$ Temperature of seafloor surface at site 4 .

${ }^{\mathrm{b}}$ Data are the means of two replicates using $200 \mathrm{ml}$ of seafloor sediment from each sampling site. nt, not tested.

${ }^{c}$ See sampling sites in Figure 1. 
Table 3. Detection of Pythium porphyrae from seafloor sediment of the Ariake Sea by nested polymerase chain reaction (PCR) in 2000 ${ }^{\mathrm{a}}$

\begin{tabular}{|c|c|c|c|c|c|c|c|c|c|c|}
\hline \multirow[b]{2}{*}{ Sampling date } & \multicolumn{10}{|c|}{ Detection of $P$. porphyrae } \\
\hline & $1^{\mathrm{c}}$ & 3 & 4 & 5 & 6 & 8 & 10 & 11 & 12 & 13 \\
\hline $22 \mathrm{Feb}$ & - & - & - & - & - & - & - & - & - & - \\
\hline 11 May & $\mathrm{nt}$ & $\mathrm{nt}$ & + & nt & nt & nt & - & nt & nt & nt \\
\hline 4 July & nt & $\mathrm{nt}$ & - & nt & nt & nt & $\mathrm{nt}$ & nt & nt & $\mathrm{nt}$ \\
\hline 22 Aug & nt & nt & + & nt & nt & nt & - & nt & nt & nt \\
\hline 26 Oct & nt & nt & - & nt & $\mathrm{nt}$ & nt & $\mathrm{nt}$ & $\mathrm{nt}$ & nt & nt \\
\hline
\end{tabular}

a According to the procedure of Yokoo et al. (28).

b -, not detected; +, detected. Results from $200 \mathrm{ml}$ of seafloor sediment from each sampling site. nt, not tested.

c See sampling sites in Figure 1.

Table 4. Detection of Pythium porphyrae from seafloor sediment of the Ariake Sea by direct polymerase chain reaction (PCR) using species-specific primers $^{\mathrm{a}}$

\begin{tabular}{|c|c|c|c|c|c|c|c|c|c|}
\hline \multirow[b]{2}{*}{ Sampling date } & \multicolumn{9}{|c|}{ Detection of $P$. porphyrae } \\
\hline & $1^{\mathrm{c}}$ & 3 & 4 & 5 & 6 & 7 & 8 & 9 & 10 \\
\hline \multicolumn{10}{|l|}{2001} \\
\hline 29 May & - & - & - & - & - & - & - & - & - \\
\hline $30 \mathrm{Aug}$ & nt & nt & - & $\mathrm{nt}$ & nt & $\mathrm{nt}$ & - & $\mathrm{nt}$ & - \\
\hline 20 Nov & nt & nt & - & nt & nt & nt & - & nt & - \\
\hline \multicolumn{10}{|l|}{2002} \\
\hline 10 May & nt & nt & + & nt & nt & nt & - & nt & + \\
\hline $18 \mathrm{Sep}$ & nt & nt & - & nt & nt & nt & - & $\mathrm{nt}$ & - \\
\hline $29 \mathrm{Oct}$ & nt & nt & - & $\mathrm{nt}$ & nt & nt & nt & nt & nt \\
\hline
\end{tabular}

a Park et al. (18).

b -, not detected; +, detected. Results from $200 \mathrm{ml}$ of seafloor sediment from each sampling site. nt, not tested.

c See sampling sites in Figure 1.

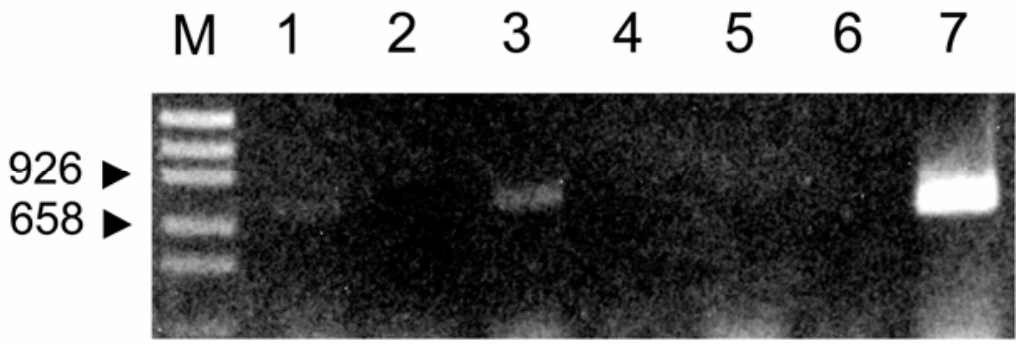

Fig. 5. Agarose gel electrophoresis of polymerase chain reaction (PCR)-amplified products from DNA extracts from seafloor sediment of the Ariake Sea using a Pythium porphyrae-specific primer (18). Lane M: pHY Marker (Takara Bio). Lanes 1, 2, and 3: Seafloor sediment samples from sites 4, 8, and 10, respectively, on 10 May 2002. Lanes 4 and 5: Seafloor sediment samples from sites 4 and 10, respectively, on 18 September 2002. Lane 6: Negative control (autoclaved seafloor soil). Lane 7: Positive control (purified genomic DNA of $P$. porphyrae isolate G1).

no positive correlation was found between propagule density and distance from the river mouth. Frequency of the pathogen did not differ among sites near major river mouths (Fig. 1, sites 1, 3, and 6) and the other sites. Although the numbers of sampling sites were limited and detection levels of the pathogen were low, the present results combined with sea farm observations suggest that factors other than the presence of pathogen propagules influence primary infections. The seawater near the river mouths is shallow and is therefore warmer than the rest of the area. The water is consistently diluted by the fresh water from rivers. It is well known that high temperature and low salinity conditions stress the nori, predisposing it to $P$. porphyrae infection $(4,5,11,22)$. The environmental stress is likely to be more important than the presence of $P$. porphyrae propagules in the seafloor sediment to establish primary infections of the disease.

\section{ACKNOWLEDGMENTS}

We gratefully acknowledge Professor Satoshi T. Ohki, Osaka Prefecture University, Japan, and Frank Martin, U.S. Agricultural Research Station, Salinas, CA, USA, for their valuable comments.

\section{LITERATURE CITED}

1. Altschul, S. F., Gish, W., Miller, W., Myers, E. W., and Lipman, D. J. 1990. Basic local alignment search tool. J. Mol. Biol. 215:403410 .

2. Amano, H., Sakaguchi, K., Maegawa, M., and Noda, H. 1996. The use of a monoclonal antibody for the detection of fungal parasite, $P y$ thium sp., the causative organism of red rot disease, in seawater from Porphyra cultivation farms. Fish. Sci. 62:556-560.

3. Arasaki, S. 1947. Studies on rot diseases of Jpn. Soc. Sci. Fish. 13:74-90.

4. Arasaki, S. 1956. Disease cycle and control of rot diseases of Porphyra tenera Kjellm. (in Japanese) Shokubutsu Boeki 10:243-246.

5. Arasaki, S. 1962. Studies on the artificial culture of Porphyra tenera Kjellm III. On the red wasting disease of Porphyra, especially on the physiology of the causal fungus Pythium Porphyra tenera Kjellm. (in Japanese) Bull. sp. nov. (in Japanese with English summary) J. Agric. Lab. 3:87-93.

6. Arasaki, S., Akino, K., and Tomiyama, T. 1968. A comparison of some physiological aspects in a marine Pythium on the host and on the artificial medium. Bull. Misaki. Marine Biol. Inst., Tokyo Univ. 12:203-206.

7. Fujita, Y. 1978. Studies on pathogenic Pythium of laver red rot in Ariake Sea farm V. Germination of Pythium porphyrae oospores. (in Japanese with English summary) Bull. Jpn. Soc. Sci. Fish. 44:15-19.

8. Fujita, Y. 1990. Diseases of cultivated Porphyra in Japan. Pages 177-190 in: Introduction to Applied Phycology. I. Akatsuka, ed. SPB Academic Publishing, The Hague.

9. Fujita, Y., and Zenitani, B. 1977. Studies on pathogenic Pythium of laver red rot in Ariake Sea farm II. Experimental conditions and nutritional requirements for growth. (in Japanese with English summary) Bull. Jpn. Soc. Sci. Fish. 43:89-95.

10. Fujita, Y., and Zenitani, B. 1977. Studies on pathogenic Pythium of laver red rot in Ariake Sea farm III. Environmental and nutritional conditions for production of sexual organs. (in Japanese with English summary) Bull. Jpn. Soc. Sci. Fish. 43:921-927.

11. Kato, S., Watanabe, T., and Sato, Y. 1973 Studies on the diseases of cultural PorphyraVII. A comparison of physiological properties among the different isolates of the causal fungus of the red wasting disease. (in Japanese with English summary) Bull. Jpn. Soc. Sci. Fish. 39:859-865.

12. Kazama, F. Y. 1979. Pythium 'red rot disease' of Porphyra. Experientia 35:443-444.

13. Kazama, F. Y., and Fuller, M. S. 1970. Ultrastructure of Porphyra perforate infected with Pythium marinum, a marine fungus. Can. J. Bot. 48:2103-2107.

14. Kazama, F. Y., and Fuller, M. S. 1973. Mineral nutrition of Pythium marinum, a marine facultative parasite. Can. J. Bot. 51:693-699.

15. Kazama, F. Y., and Fuller, M. S. 1977. Colonization of Porphyra perforate thallus discs by Pythium marinum, a marine facultative para- 
site. Mycologia 69:246-254.

16. Martin, F. N. 1992. Pythium. Pages 39-49 in: Methods for research on soilborne phytopathogenic fungi. L. L. Singleton, J. D. Mihail, and C. M. Rush, eds. American Phytopathological Society, St. Paul, MN.

17. Martin, F. N., and Kistler, H. C. 1990. Speciesspecific banding patterns of restriction endonuclease-digested mitochondrial-DNA from the genus Pythium. Exp. Mycol. 14:32-46.

18. Park, C. S., Kakinuma, M., and Amano, H. 2001. Detection of the red rot disease fungi Pythium spp. by polymerase chain reaction. Fish. Sci. 67:197-199.

19. Park, C. S., Kakinuma, M., and Amano, H. 2001. Detection and quantitative analysis of zoospores of Pythium porphyrae, causative organism of red rot disease in Porphyra, by competitive PCR. J. Appl. Phycol. 13:433-441.

20. Park, C. S., Sakaguchi, K., Kakinuma, M., and Amano, H. 2000. Comparison of the morphological and physiological features of the red rot disease fungus Pythium sp. isolated from Por- phyra yezoensis from Korea and Japan. Fish. Sci. 66:261-269.

21. Park, C. S., Sakaguchi, K., Kakinuma, M., and Amano, H. 2000. Comparison of electrophoretic patterns of soluble proteins and isozymes of the red rot disease fungus Pythium sp. isolated from Porphyra yezoensis from Korea and Japan. Fish. Sci. 66:1158-1162.

22. Sasaki, M., and Sakurai, Y. 1972. Comparative observations on the growth among the five strains in Pythium porphyrae under the same cultural condition. (in Japanese with English summary) Bull. Tohoku Reg. Fish. Res. Lab. 32:83-87.

23. Takahashi, M., Ichitani, T., and Sasaki, M. 1977. Pythium porphyrae Takahashi et Sasaki, sp. nov. causing red rot of marine red algae Porphyra spp. Trans. Mycol. Soc. Jpn. 18:279285.

24. Uppalapati, S. R., and Fujita, Y. 2000. Carbohydrate regulation of attachment, encystment and appressorium formation by Pythium porphyrae (Oomycota) zoospores on Porphyra ye- zoensis (Rhodophyta). J. Phycol. 36:359-366.

25. Van der Gaag, D. J., and Frinking, H. D. 1997. Extraction of oospores of Peronospora viciae from soil. Plant Pathol. 46:675-679.

26. Van der Plaats-Niterink, A. J. 1981. Monograph of the genus Pythium. Stud. Mycol 21:1-242.

27. White, T. J., Bruns, T., Lee, S., and Taylor, J. 1990. Amplification and direct sequencing of fungal ribosomal RNA genes for phylogenetics. Pages 315-322 in: PCR Protocols. A Guide to Methods and Applications. M. A. Innis, D. H. Gelfand, J. J. Sninsky, and T. J. White, eds. Academic Press, San Diego, CA.

28. Yokoo, K., Kawamura, Y., Kawahara, I., Tojo, M., and Mizukami, Y. 2000. Detection of oospores of Pythium porphyrae, from sterile sediments by using PCR. (in Japanese with English summary) Suisanzoshoku 48:679-680.

29. Yokoo, K., Kawamura, Y., and Tojo, M. 1999. Oospore survival of Pythium porphyrae, in sterile sediments. (in Japanese) Bull. Saga Pref. Ariake Fish Res. Devel. Cent. 19:1-7. 